\title{
Hak-Hak Narapidana Wanita di Lembaga Pemasyarakatan Kelas II A Watampone Perspektif Undang-Undang Nomor 12 Tahun 1995 tentang Pemasyarakatan
}

\author{
Mirnawati D \\ Institut Agama Islam Negeri (IAIN) Bone \\ mirnawati99@gmail.com
}

\begin{abstract}
Abstrak
Penelitian ini bertujuan untuk mengetahui implementasi hak-hak narapidana wanita di Lembaga Pemasyarakatan Kelas II A Watampone. Narapidana wanita merupakan narapidana yang harus dilindungi dan diberikan haknya dengan kodrat yang ia miliki, diantaranya menstruasi, hamil, melahirkan dan menyusui. Dengan kodrat inilah menjadi landasan utama perlu ada perlindungan hukum terhadap narapidana wanita. Dengan adanya perlindungan hukum, maka selanjutnya akan diterapkan dalam Lembaga Pemasyarakatan.Hasil penelitian ini menunjukkan bahwa Implementasi Hak-Hak Narapidana Wanita di Lembaga Pemasyarakatan Kelas II A Watampone belum terlaksana secara maksimal, mengakibatkan narapidana wanita merasa tidak sepenuhnya puas dengan pelayanan yang diberikan. Hal tersebut dikarenakan beberapa kendala diantaranya Lemabaga Pemasyarakatan Kelas II AWatampone merupakan LAPAS umum (bukan LAPAS khusus wanita) sehingga pemenuhan hak-hak narapidana wanita sama dengan hak-hak narapidana secara umum. Keterbatasan petugas wanita sehingga untuk bersentuhan langsung terkait masalah wanita tentu narapidana wanita merasa terbatasi. Keterbatasan anggaran, sehingga untuk memenuhi kebutuhan narapidana wanita, seperti memberikan makanan tambahan secara rutin, baik kepada bayi maupun ibunya tidak dapat terlaksana. Menyediakan tenaga kesehatan lainnya juga tidak dapat dilaksanakan oleh Petugas Lembaga Pemasyarakatan Kelas II A Watampone. Keterbatasan tenaga kesehatan, dengan dua jumlah perawat dan satu sebagai dokter bantu tentu tidak dapat mengontrol kesehatan seluruh narapidana wanita dengan jumlah 12 orang, terlebih pada ibu yang menyusui dan juga bayinya yang berumur 1 tahun 2 bulan.
\end{abstract}

\section{Kata Kunci : Hak-Hak Narapidana Wanita, Undang-Undang Nomor 12 Tahun 1995 tentang Pemasyarakatan}

\section{PENDAHULUAN}

Hukum diciptakan sebagai suatu sarana atau instrumen untuk mengatur hakhak dan kewajiban-kewajiban subjek hukum, agar masing-masing subjek hukum dapat menjalankan kewajibannya dengan baik dan mendapatkan haknya secara wajar, hukum juga berfungsi sebagai instrumen perliundungan bagi subjek hukum, jika dikaitkan dengan keberadaan suatu negara, hukum dapat difungsikan sebagai perlindungan 
warga negara dari tindakan pemerintah yang tiran dan absolut. ${ }^{95}$

Negara Indonesia merupakan negara hukum, maka sepantasnya dan selayaknya hukum harus ditegakkan demi keadilan. Penegakan hukum adalah proses dilakukannya upaya untuk tegaknya atau berfungsinya norma-norma hukum secara nyata sebagai pedoman prilaku dalam lalu lintas atau hubungan-hubungan hukum dalam kehidupan bermasyarakat dan bernegara. ${ }^{96}$

Hukum pidana di Indonesia terbagi dua, yaitu hukum pidana umum dan hukum pidana khusus. Secara defenitif, hukum pidana umum dapat diartikan sebagai perundang-undangan pidana dan dapat berlaku umum, yang tercantum dalam kitab Undang-Undang Hukum Pidana (KUHP) serta semua perundang-undangan yang mengubah dan menambah KUHP. Adapun hukum pidana khusus (Peraturan Perundang-Undangan Tindak Pidana Khusus) bisa dimaknai sebagai perundangundangan di bidang tertentu yang memiliki sanksi pidana, atau tindak-tindak pidana yang diatur dalam perundang-undangan khusus di luar KUHP, baik perundangundangan pidana maupun bukan pidana tetapi memiliki sanksi pidana (ketentuan yang menyimpang dari KUHP). ${ }^{97}$ Membahas mengenai hukum pidana, sangat jelas proses pemidanaan. Setelah mendapat putusan akhir dari pengadilan, maka selanjutnya adalah terdakwa akan menjalani hukuman sebagai narapidana dalam lembaga pemasyarakatan.

Pemasyarakatan menurut Undang-Undang No. 12 Tahun 1995 adalah bagian dari tata peradilan pidana dari segi pelayanan tahanan, pembinaan narapidana, anak pidana, dan bimbingan klien pemasyarakatan yang dilaksanankan secara terpadu (dilaksanakan bersama-sama dengan aparat penegak hukum) dengan tujuan agar

\footnotetext{
${ }^{95}$ Bahder Johan Nasution, Negara Hukum dan Hak Asasi Manusia (Cet. II; Bandung: Cv Mandar Maju, 2012) h. 258.

${ }^{96}$ Bahder Johan Nasution, Negara Hukum dan.... h. 259.

${ }^{97}$ Aziz Syamsuddin, Tindang Pidana Khusus, Ed. I (Cet. IV; Jakarta: Sinar Grafika, 2014) h. 8. Jurnal Al-Dustur; VOLUME 2 NO 1, JUNI 2019
} 
setelah mereka menjalani pidananya dapat menjadi warga masyarakat yang baik. ${ }^{98}$ Ketentuan itu bermakna bahwa, penegak hukum di Indonesia tidak serta merta berhenti pada proses peradilan, akan tetapi masih berlanjut hingga terpidana berada didalam lembaga pemasyarakatan. Pada tataran inilah lembaga pemasyarakatan memainkan perannya dalam pemberian pembinaan dan pengamanan terhadap terpidana sesuai dengan perundang-undangan yang berlaku. Tugasnya hanya dilakukan oleh Lembaga Pemasyarakatan (LAPAS), Rumah Tahanan Negara (RUTAN), Rumah Penyimpanan Benda Sitaan Negara (RUPBASAN), dan Balai Pemasyarakatan (BAPAS). ${ }^{99}$ Hukum selalu disertai dengan sanksi bagi pelanggarnya, namun sanksi ini bukanlah merupakan jaminan agar warga tidak lagi melakukan kejahatan.

Terlebih lagi sanksi hukum pidana merupakan Remedium, yang mengandung sifat kontradiktif/paradoksal dan mengandung unsur atau efek samping yang negatif. Penggunaan hukum pidana dalam menanggulangi kejahatan hanya merupakan hal yang bertujuan menanggulangi/menyembuhkan gejala. Hukum sanksi pidana hanya merupakan pengobatan simbiotik dan bukan pengobatan kasuistik, karena sifat-sifat kejahatan yang demikian kompleks di luar jangkauan hukum pidana. ${ }^{100}$ Untuk itu, hukum haruslah pandai menempatkan sesuatu sesuai dengan citra dan tujuan negara, khusus kepada sanksi bagi pelanggarnya.

Dalam Lembaga Pemasyarakatan Kelas II A Watampone, ada beberapa narapidana laki-laki, anak dan wanita. Khusus membahas mengenai narapidana wanita, ada beberapa hak dari mereka yg harus dilindungi. Sebagaimana yang dikatakan oleh Prof. Dr. Jur Andi Hamzah bahwa yang dilindungi adalah perempuan, alasannya karena

${ }^{98}$ Rika Saraswati, Hukum Perlindungan Anak di Indonesia (Cet. I; Semarang: PT. Citra Aditya Bakti, 2009) h. 133.

${ }^{99}$ Syaiful Bakhri, Kebijakan Kriminal (Cet. I; Yogyakarta: Total Media, 2010) h. 145.

${ }^{100}$ Dr. H. Syaiful Bakhri, S.H., M.H., Kebijakan.... h. 21. Jurnal Al-Dustur; VOLUME 2 NO 1, JUNI 2019 
perempuan dapat hamil. ${ }^{101}$

Wanita dalam hal ini, seorang yang juga sebagai ciptaan-Nya harus dilindungi dan diberikan haknya, karenanya banyak hal yang dialami wanita dan tidak dialami oleh laki-laki seperti halnya menstruasi, hamil dan menyusui. Jelas dikatakan dalam Peraturan Pemerintah Nomor 32 Tahun 1999 tentang Syarat dan Tata Cara Pelaksanaan Hak Warga Binaan Pasal 20 ayat (1) bahwa narapidana dan anak didik pemasyarakatan yang sakit, hamil atau menyusui berhak mendapatkan makanan tambahan sesuai dengan petunjuk dokter. Selain itu, nampak jelas bahwa antara pria dan wanita meskipun sama dimuka hukum, akan tetapi sebagai kodrat wanita seperti menstruasi, mengandung, melahirkan dan menyusui. Dengan demikian selayaknya wanita mendapatkan haknya yang sedemikian rupa telah diatur dalam undang-undang. Olehnya itu, selayaknya petugas Lembaga Pemasyarakatan Kelas II A Watampone merealisasikan sesuai dengan undang-undang tersebut. Karena tanpa memperhatikan hal-hal yang harus diberikan pada narapidana wanita, akan menimbulkan maslah dalam dirinya. Baik itu kekerasan fisik ataupun kekerasan seksual.

Dari beberapa uraian diatas yang kemudian menjadi dasar utama penulis tertarik membahas mengenai narapidana wanita, mengemukakan hak-hak yang dimiliki oleh wanita, baik wanita yang hamil, sakit, menstruasi ataupun yang menyusui (termasuk yang memelihara anaknya dalam lembaga). Kemudian mengemukakan pula tentang bagaimana harusnya narapidana mengalami perubahan baik setelah keluar dari lembaga tersebut. Sehingga didikan narapidana wanita di Lembaga Pemasyarakatan Kelas II A Watampone dapat kembali berguna, tidak terjadi penekanan, pemerasa dan pemberlakuan buruk sehingga setelah mereka keluar dari LAPAS dapat hidup normal dan diterima oleh masyarakat.

Berdasarkan latar belakang masalah diatas, maka yang menjadi pokok masalah dalam penelitian ini adalah bagaimana Implementasi Undang-Undang Nomor 12

${ }^{101}$ Jur Andi Hamzah, Delik-Delik Tertentu (Special Delicten) Ed. II (Cet. I; Jakarta: Sinar Grafika, 2015) h. 22.

Jurnal Al-Dustur; VOLUME 2 NO 1, JUNI 2019 
Tahun 1995 tentang Pemasyarakatan (Studi terhadap Hak-Hak Narapidana Wanita di Lembaga Pemasyarakatan Kelas II A Watampone). Berdasarkan pokok masalah tersebut, membagi ke dalam sub-sub masalah tentang Bagaimana implementasi hakhak narapidana wanita di Lembaga Pemasyarakatan Kelas II A Watampone dan Bagaimana kendala yang dihadapi petugas Lembaga Pemasyarakatan Kelas II A Watampone dalam mengimplementasikan hak-hak narapidana wanita?

\section{METODE PENELITIAN}

1. Jenis dan Pendekatan Penelitian

Jenis penelitian yang digunakan adalah penelitian lapangan yang langsung berkomunikasi dan mencari informasi kepada narapidana wanita yang ada dan menjalani pidana atau putusan akhir pengadilan di Lembaga Pemasyarakatan Kelas II A Watampone.

Penelitian hukum normatif empiris yakni penelitian hukum yang memadukan antara penelitian hukum normatif dan penelitian hukum sosial. Pada jenis penelitian semacam ini peneliti melakukan penelitian dengan mengkombain kedua tipe penelitian sebagaimana disebutkan di atas dalam sebuah penelitian. ${ }^{102}$ Pendekatan hukum normatif empiris inilah yang kemudian digunakan penulis dalam meneliti masalah.

2. Lokasi penelitian

Adapun lokasi penelitian penulis yaitu di Lembaga Pemasyarakatan (LAPAS) Kelas II A Watampone di Jl. Laksamana Yos Sudarso. Alasan Penulis mengambil lokasi ini karena penulis ingin mengetahui bagaimana penerapan hak-hak narapidana wanita di Lembaga Pemasyarakatan Kelas II A Watampone.

3. Data dan Sumber Data

a. Data Primer adalah data yang diperoleh secara langsung di Lapangan yang merupakan data mentah ( raw data) yang masih memerlukan pengolahan lebih

\footnotetext{
${ }^{102}$ Syarifuddin Nawi, Penelitian hukum.... h. 9. 
lanjut. Data semacam ini diperoleh melalui wawancara atau intervieuw ataupun diperoleh melalui pendengaran angket atau kuesioner. Dalam hal ini masyarakat tertentu yang diperoleh lewat informasi dan dokumen.

b. Data sekunder yaitu data yang berupa dokumen-dokumen, jurnal-jurnal ilmiah, artikel ilmiah yang diperoleh dari sebuah instansi pemerintah atau swasta. Berbeda dengan data primer yang belum diolah, maka data sekunder adalah data yang sudah diolah. ${ }^{103}$

\section{Instrumen Penelitian}

Instrumen penelitian adalah alat yang digunakan oleh peneliti dalam melakukan proses pengumpulan data. Adapun instrument yang digunakan peneliti yaitu kamera, recorder, daftar wawancara, alat tulis menulis.

\section{Teknik Pengumpulan Data}

Untuk memperoleh informasi terkait masalah yang akan diteliti penulis, maka teknik yang digunakan untuk mengumpulkan data adalah,

a. Observasi yaitu penelitian dengan mendatangi lokasi penelitian, mengadakan pengamatan langsung terhadap objek yang diteliti.

b. Wawancara atai interview yaitu mendapatkan data dengan mengadakan tanya jawab dengan responden yaitu pegawai dan narapidana wanita di Lembaga Pemasyarakatan Kelas II A Watampone

c. Dokumentasi artinya penulis mengambil beberapa gambar pada lokasi guna kelengkapan penelitian.

\section{Teknik Analisis Data}

Proses analisis data dalam penelitian kualitatif dimulai dengan menelaah seluruh data yang terkumpul dari berbagai sumber, yaitu dari wawancara, pengamatan yang sudah dituliskan dalam catatan lapangan, dokumen pribadi, dokumen resmi,

\footnotetext{
${ }^{103}$ Syarifuddin Nawi, Penelitian hukum.... h. 29. Jurnal Al-Dustur; VOLUME 2 NO 1, JUNI 2019
} 
gambar, foto dan sebagainya. ${ }^{104}$ Penelitian kualitatif sering disebut teori lensa (lens theory) atau teori perspektif. ${ }^{105}$

Berdasarkan uraian mengenai kualitatif di atas, maka penulis menggunakan analisis ini, yaitu kualitatif. Karena penulis tidak berdasar pada rumus-rumus statistic melainkan lebih kepada menelaah dari berbagai sumber, misalnya wawancara, dokumen resmi dll.

\section{HASIL PENELITIAN DAN PEMBAHASAN}

\section{Pembinaan Narapidana Wanita di Lembaga Pemasyarakatan Kelas II A Watampone}

Petugas Lembaga Pemasyarakatan Kelas II A Watampone dalam dalam memberikan pelayanan, pembimbingan dan pembinaan kepada narapidana wanita sama dengan pelayanannya terhadap narapidana laki-laki. Lembaga Pemasyarakatan Kelas II A Watampone merupakan Lembaga Pemasyarakatan umum, untuk itu, dalam pemberian pelayanan terhadap narapidana tetap berpedoman pada Undang-Undang Nomor 12 Tahun 1995 tentang Pemasyarakatan.

Lembaga Pemasyarakatan Kelas II A Watampone Merupakan LAPAS umum, jadi hak narapidana wanita sama dengan hak narapidana laki-laki. Melindungi hak narapidana wanita dengan menerapkan Undang-Undang Nomor 12 tahun 1995 tentang Pemasyarakatan selama narapidana wanita memenuhi kewajibannya dengan berkelakuan baik. Yang dimaksud dengan berkelakuan baik diantaranya tidak melanggar tata tertib yang ada. Dalam menerapkan pembinaan, pendidikan dan pembimbingan narapidana wanita, pegawai Lembaga Pemasyarakatan Kelas II A Watampone cukup melaksanakan sesuai standar operasional serta memberikan kesempatan narapidana wanita untuk komplain.

Pegawai memberikan pembinaan demi kebutuhan narapidana wanita seperti

\footnotetext{
${ }^{104}$ Syarifuddin Nawi, Penelitian hukum.... h. 53.

${ }^{105}$ Sugiyono, Metode Penelitian Kombinasi, (Cet. III; Yogyakarta: ALFABETA, 2012), h.295 Jurnal Al-Dustur; VOLUME 2 NO 1, JUNI 2019
} 
pembinaan keagamaan (pengajian) dan kemandirian (berupa pelatihan keterampilan). ${ }^{106}$

\section{Tabel}

Daftar Nama-Nama Narapidana Wanita di Lembaga Pemasyarakatan Kelas II A Watampone:

\begin{tabular}{|c|c|c|c|c|c|}
\hline No. & $\begin{array}{c}\text { Nama } \\
\text { (Inisial) }\end{array}$ & Umur & Status & Agama & Ket. \\
\hline 1. & "NH" & $26 \mathrm{Th}$ & Kawin & Islam & \\
\hline 2. & "RW" & $22 \mathrm{Th}$ & Belum Kawin & Islam & \\
\hline 3. & "MD" & $22 \mathrm{Th}$ & Janda & Islam & \\
\hline 4. & "FT" & $22 \mathrm{Th}$ & Janda & Islam & \\
\hline 5. & "IA" & $23 \mathrm{Th}$ & Belum Kawin & Islam & \\
\hline 6. & "SR" & $33 \mathrm{Th}$ & Kawin & Islam & Merawat bayi \\
\hline 7. & "AM" & $46 \mathrm{Th}$ & Kawin & Islam lembaga & \\
\hline 8. & "SM" & $42 \mathrm{Th}$ & Kawin & Islam & \\
\hline 9. & "IS" & $21 \mathrm{Th}$ & Belum Kawin & Islam & \\
\hline 10. & "HR" & $29 \mathrm{Th}$ & Kawin & Islam & \\
\hline 11. & "FT" & $33 \mathrm{Th}$ & Kawin & Islam & \\
\hline 12. & "BT" & $36 \mathrm{Th}$ & Kawin & Islam & \\
\hline
\end{tabular}

Sumber Data: Data Dokumen Sub Bagian Registrasi LAPAS Kelas II A Watampone, Tahun 2018

Lembaga Pemasyarakatan merupakan rumah bagi mereka narapidana untuk belajar hingga dapat berguna bagi masyarakat dan dapat pula diterima setelah keluar dari lembaga pemasyarakatan. Untuk itu, pemasyarakatan haruslah mengayomi dan

${ }^{106}$ Azhar, S.H, Kepala Bagian Registrasi, Wawancara oleh Penulis, di LAPAS KELAS II A WATAMPONE, 7 November 2017 
berikan bekal hidup agar mereka dapat menjalankan peranannya sebagai warga masyarakat yang baik dan berguna. Negara tidak berhak membuat seseorang lebih buruk/lebih jahat daripada sebelum dijatuhi pidana. Pekerjaan yang diberikan kepada narapidana dan anak didik tidak boleh bersifat sekedar mengisi waktu, atau kepentingan negara sewaktu saja.

Ketertiban adalah merupakan prinsip kerja pegawai Lembaga Pemasyarakatan Kelas II A Watampone. Untuk menjaga ketertiban tersebut, ada beberapa aturan yang kemudian dibuat dalam selebaran kertas lalu ditempatkan pada pintu masuk sel narapidana wanita. Aturan yang dimaksud diantaranya:

1) Taat dan patuh pada semua aturan yang berlaku di LAPAS.

2) Menjaga tata karma sesame penghuni LAPAS.

3) Menjaga sopan santun kepada petugas dan sesame penghuni.

4) Memelihara kebersihan dan keindahan dalam lingkungan serta barang inventaris yang dipinjamkan LAPAS.

5) Wajib memakai baju seragam napi (biru) dan tahanan (rompi hijau) pada saat menerima kunjungan

6) Wajib bekerja sesuai dengan arahan petugas.(gambar terlampir) $)^{107}$

Berdasarkan uraian tabel narapidana wanita di atas, terdapat dua belas (12) orang narapidana, satu diantaranya yang merawat dan memelihara anaknya di dalam lembaga. Dua belas (12) narapidana wanita ini kemudian disatukan dalam kamar dengan kapasitas kamar mencapai 15 orang. Dengan jumlah dua belas (12) orang narapidana wanita dan satu diantaranya merawat anaknya di dalam lembaga, tentu hak narapidana untuk mendapatkan perawatan kesehatan sebagaimana dimaksud pada Undang-Undang Nomor 12 Tahun 1995 tentang Pemasyarakatan dengan jumlah tenaga kesehatan 3 orang ( 2 perawat dan 1 dokter bantu) tanpa tenaga kesehatan bidan tidak berjalan dengan maksimal. Terlebih kepada perawatan kesehatan ibu menyusui dan

\footnotetext{
${ }^{107}$ Azhar, S.H, Kepala Bagian Registrasi, Wawancara.... 7 November 2017 Jurnal Al-Dustur; VOLUME 2 NO 1, JUNI 2019
} 
bayinya yang harusnya ditangani langsung oleh bidan.

\section{Jenis-Jenis Bebas Bersyarat}

Bebas bersyarat ada 4 jenis diantaranya;
a. PB (Pembebasan Bersayat)
b. CMB (Cuti Menjelang Bebas)
c. $\mathrm{CB}$ (Cuti Bersyarat)
d. CMK ( Cuti Mengunjungi Keluarga)

Secara regulasi, tidak ada aturan mengenai pemenuhan hak biologis narapidana wanita. Meski ada beberapa LAPAS di kota-kota besar yang menyediakan tempat khusus untuk pemenuhan hak biologis bagi narapidana yang berstatus kawin, namun khusus pada Lembaga Pemasyarakatan Kelas II A Watampone, pimpinan lembaga tidak mengeluarkan kebijakan khusus masalah pemenuhan hak biologis. ${ }^{108}$

Pemenuhan hak biologis narapidana wanita hanya dapat dilakukan dalam proses pembebasan bersyarat. Pembebasan bersyarat dapat diberikan kepada narapidana dan anak didik pemasyarakatan kecuali anak sipil yang telah memenuhi syarat, telah menjalani masa pidana paling singkat $2 / 3$ (dua per tiga) dengan ketentuan 2/3 (dua per tiga) masa pidana tersebut paling sedikit 9 bulan, dengan ketentuan wajib lapor kepada pihak BAPAS selama kurun waktu yang ditentukan.

Jenis bebas bersyarat di atas berlaku untuk semua narapidana yang telah memenuhi persyaratan. Mereka berhak memenuhi kebutuhan biologisnya dan kebutuhan lain diluar tannggungjawab LAPAS, karena selama bebas bersyarat berlaku, maka pihak BAPAS yang memiliki tanggungjawab penuh kecuali CMK (Cuti Mengunjungi Keluarga), yang masih dibawah tanggungjawab LAPAS. Selebihnya, tidak ada kebijakan lain. Sehingga hal demikian dapat dijadikan sebagai efek jerah dan tidak berpikir untuk megulangi kejahatan yang dilakukan. ${ }^{109}$

\footnotetext{
${ }^{108}$ Andi Siti Hardiyanti Amir, Seksi Bimaswat, Wawancara oleh Penulis, 9 Mei 2018

${ }^{109}$ Suprianto,S.H.,M.H, Kasubseksi Bimaswat, Wawancara oleh Penulis, 9 Mei 2018 Jurnal Al-Dustur; VOLUME 2 NO 1, JUNI 2019
} 


\section{A. Kendala yang Dihadapi Pegawai Lembaga Pemasyarakatan Kelas II A Watampone dalam Mengimplementasikan Hak-Hak Narapidana Wanita}

Pada dasarnya hak antara narapidana wanita dan narapidana pria pada dasarnya sama, hanya dalam hal ini karena narapidananya adalah wanita maka ada beberapa hak yang mendapat perlakuan khusus dari narapidana pria yang berbeda dalam beberapa hal, di antaranya karena wanita mempunyai kodrat yang tidak dimiliki oleh narapidana pria yaitu menstruasi, hamil, melahirkan, dan menyusui maka dalam hal ini hak-hak narapidana wanita perlu mendapat perhatian yang khusus baik menurut UndangUndang maupun berupa kebijakan oleh petugas lembaga pemasyarakatan.

Memenuhi hak-hak narapidana wanita tentu menjadi tanggung jawab Petugas Lembaga Pemasyarakatan kelas II A Watampone. Namun, pemenuhan hak-hak narapidana wanita tersebut tidak terlalu ditekankan oleh Petugas Lembaga Pemasyarakatan Kelas II A Watampone, dikarenakan beberapa alasan sebagai berikut;

1) Lembaga Pemasyarakatan Kelas II AWatampone merupakan LAPAS umum (bukan LAPAS khusus wanita) sehingga pemenuhan hak-hak narapidana wanita sama dengan hak-hak narapidana secara umum.

2) Keterbatasan petugas wanita sehingga untuk bersentuhan langsung terkait masalah wanita tentu narapidana wanita merasa terbatasi.

3) Keterbatasan anggaran, sehingga untuk memenuhi kebutuhan narapidana wanita, seperti memberikan makanan tambahan secara rutin dan menyediakan tenaga kesehatan lainnya tidak dapat dilaksanakan oleh Petugas Lembaga Pemasyarakatan Kelas II A Watampone.

4) Keterbatasan tenaga kesehatan, sehingga untuk memenuhi hak memperoleh perawatan kesehatan yang layak pun tidak terealisasi maksimal. Dengan dua jumlah perawat dan satu sebagai dokter bantu tentu tidak dapat mengontrol kesehatan seluruh narapidana wanita dengan jumlah 12 orang, terlebih pada ibu yang menyusui dan juga bayinya yang berumur 1 tahun 2 bulan. Jumlah tenaga kesehatan yang ada dalam lembaga, tentu menjadi kendala pokok sehingga hak- 
hak narapidana wanita tidak terlaksana secara maksimal. Tanpa tenaga kesehatan bidan, tentu perawatan ibu menyusui dan juga untuk bayi tidaklah berjalan maksimal pula. Sebagai bukti konkrit bahwa bayi dalam lembaga yang berumur 1 tahun 2 bulan pernah mengalami sakit yakni gejala tipes. Hal tersebut dikarenakan kurangnya perhatian kesehatan yang diberikan pada bayi dan juga ibunya.

Melihat beberapa faktor di atas, tentu bukan hal yang tidak mungkin jika ada beberapa narapidana wanita yang komplain dan merasa tidak puas dengan pelayanan yang diberikan pegawai terhadap narapidana khusus pada narapidana wanita.

\section{PENUTUP}

Berdasarkan hasil analisis dan pembahasan, maka dapat dikemukakan kesimpulan bahwa:

1. Implementasi Undang-Undang Nomor 12 Tahun 1995 tentang Pemasyarakatan tidak terealisasi maksimal, dengan alasan masih ada beberapa hak-hak narapidana wanita yang tidak terpenuhi, diantaranya makanan tambahan untuk ibu dan bayi kemudian mendapatkan pelayanan kesehatan yang layak. Dari jumlah keseluruhan hak-hak narapidana yang tercantum dalam UndangUndang Nomor 12 Tahun 1995 tentang Pemasyarakatan, hak narapidana wanita untuk melakukan ibadah dan mendapatkan perawatan rohani sudah terlaksana, dengan petugas Lembaga Pemasyarakatan Kelas II A Watampone menyediakan masjid dengan kapasitas 600 orang. Kemudian untuk mendapatkan pendidikan juga terlaksana yakni petugas LAPAS menyediakan perpustakaan sebagai wadah membaca. Begitupun dengan hak lain, terkecuali hak narapidana wanita untuk mendapatkan pelayanan kesehatan dan makanan yang layak inilah yang kemudian belum terlaksana dalam Lembaga Pemasyarakatan Kelas II A Watampone

2. Ada beberapa kendala yang dihadapi sehingga pemenuhan hak-hak narapidana wanita tidak terealisasi secara maksimal, yaitu Lemabaga Pemasyarakatan 
Kelas II AWatampone merupakan LAPAS umum (bukan LAPAS khusus wanita) sehingga pemenuhan hak-hak narapidana wanita sama dengan hak-hak narapidana secara umum. Keterbatasan petugas wanita sehingga untuk bersentuhan langsung terkait masalah wanita tentu narapidana wanita merasa terbatasi. Keterbatasan anggaran, sehingga untuk memenuhi kebutuhan narapidana wanita, seperti memberikan makanan tambahan secara rutin dan menyediakan tenaga kesehatan lainnya tidak dapat dilaksanakan oleh Petugas Lembaga Pemasyarakatan Kelas II A Watampone. Keterbatasan tenaga kesehatan, dengan dua jumlah perawat dan satu sebagai dokter bantu tentu tidak dapat mengontrol kesehatan khusus pada narapidana wanita yang menyusui begitupun dengan bayinya yang harusnya ditangani langsung oleh bidan. Kesehatan ibu sangatlah penting, untuk itu hak-hak narapidana yang hamil, dan menyusui berhak mendapatkan makanan tambahan. Namun dalam Lembaga Pemasyarakatan Kelas II A Watampone tidak menerapkan sesuai dengan regulasi yang mengaturnya.

\section{REFERENSI}

Ali, Achmad. Menguak Tabir Hukum. Ed. II Cet. 1; Perdana Media Group. 2015.

Bakhri, Syaiful. Kebijakan Kriminal. Cet. I; Yogyakarta: Total Media. 2010.

Djamil, M. Nasir. Anak Bukan untulk Dihukum. Cet. II; Jakarta: Sinar Grafika. 2013.

Fanani, Achmad. Kamus Istilah Populer. Cet. III; Jogjakartaa: Ar-ruzz Media. 2012.

Hamzah, Jur Andi. Delik-Delik Tertentu (Special Delicten) Ed. II. Cet. I; Jakarta: Sinar Grafika. 2015.

Handayani, Yeni. Pemenuhan Hak Kesehatan Atas Narapidana Wanita di Lembaga Pemasyarakatan Wanita Klas II A Tangerang Periode Tahun 2011. Jakarta: Perpustakaan Badan Penelitian dan Pengembangan Hak Asasi Manusia. 2012.

Kurnia, Rohmat. KUHAP dan KUHP. Cet. I; Jakarta: Bee Media Pustaka. 2014.

Lumintang, P.A.F. Hukum Penintesir Indonesia. Bandung: Armico. 1984. 
Nasution, Bahder Johan. Negara Hukum dan Hak Asasi Manusia. Cet. II; Bandung: Cv Mandar Maju. 2012.

Nawi, Syahruddin. Penelitian Hukum Normatif Versus Penelitian Hukum Empiris. Ed. II. Cet. II; Makassar: Umitoha Ukhuwah Grafika. 2013.

Pusat Pembinaan dan Pengembangan Bahasa Depdikbud. Kamus Besarv Bahasa Indonesia. Jakarta: Balai Pustaka. 1990.

Reality, Tim. Kamus Terbaru Bahasa Indonesia. Cet.i; Surabaya: Reality Publisher. 2008.

Renggong, Ruslan. Hukum acara Perdata. Cet. 1; Jakarta: Kencana. 2014.

Risky, Halim. Pemenuhan Hak Mendapatkan Makanan Yang Layak Bagi Narapidana. Makassar: Perpustakaan UIN Makassar. 2013.

Saraswati, Rika. Hukum Perlindungan Anak di Indonesia. Cet. I; Semarang: PT. Citra Aditya Bakti. 2009.

Sugiyono. Metode Penelitian Kombinasi. Cet. III; Yogyakarta: ALFABETA, 2012.

Syamsuddin, Phil. Sahiron. Studi Al-Qur'an. Cet. I; Jogjakarta: eLSAQ Press. 2010.

Syamsuddin, Aziz. Tindang Pidana Khusus. Ed. I. Cet. IV; Jakarta: Sinar Grafika. 2014. 